\title{
Application of Integration Measurement Technologies in Inventory of Bagry Water Body
}

Summary: Krakow's anthropogenic water bodies make up an attractive element of the city landscape. The largest and most-valuable in ecological, landscape and economic aspects are Bagry, Staw Płaszowski, Zakrzówek, and the complex of water bodies in Przylasek Rusiecki. Especially worth noting is the Bagry Reservoir (Zalew Bagry) located near the city center, which has yet to be thoroughly inventoried despite being used since the 1970s. The scientific studies carried out thus far have covered only selected elements of the geosphere; i.e., investigating the flora and fauna resources (biosphere and hydrosphere), searching for aggregate resources, and drilling the clay and silt by geological-engineering (lithosphere). So far, the underground part has not been geo-morphologically documented, even though Bagry has functioned as an attractive bathing resort and a sporting venue in the center of Krakow for many years. In many scientific works and press articles, a lot of information can be found on selected morphometric parameters; however, these values require verification, as they are not current for the most part and do not reflect the actual situation.

Nowadays, surveying teams have measurement and information technology tools that allow for the creation of situation and altitude maps (of the surface) and hydrographical (bathymetric) maps, which will allow for an assessment of the characteristics of the water areas and their adaptation for community purposes (recreation, sport, didactic, education, nature, etc.). This article presents the results of hydrographical measurements of Bagry and a full analysis of the morphometric parameters of the reservoir.

Keywords: Bagry, hydrographical measurements, inventory and monitoring of water resources

* AGH University of Science and Technology, Faculty of Mining Surveying and Environmental Engineering, Department of Geomatics, Krakow, Poland 


\section{Introduction}

So far, human economic activities in the area of Krakow (especially within the fluvial terrace of the Vistula River [14]) have not only lead to the disappearance of many natural water bodies, but they have also contributed to the formation of new, unique water bodies that are very interesting from geometrical and geo-morphological points of view. The exploitation of mineral resources with open-cast methods was accompanied by significant physiocoenotic changes; i.e., degradation of the vegetation and soil cover, disruption of water balance, and transformations of natural relief (surface morphology). Reclamation activities with the participation of nature have allowed for the adaptation of these water bodies to fulfill economic and social functions, emphasizing their potential function as recreational objects and ecological utilities [1].

Within the borders of Krakow, there are many water bodies whose origins can be defined based on an analysis of archival materials; i.e., reports in the popular press, scientific articles, and preserved cartographic documentation. Many of them is connected with the mining activities started in the first half of the $20^{\text {th }}$ century, when the intensive development of the city was based on the resources mined in the neighborhood of many big construction products. This referred not only to apartment buildings, but - first of all - to the development of rail connections within the city borders for the military needs of German occupation during the Second World War.

The initial formation of the water body in the area of the present Bagry Reservoir dates back to the 1920s and 30s, when natural aggregates (sand and gravel) and clay were dug up for the needs of the enterprise then called Płaszowska Fabryka Cegieł and Dachówki S.A. (the Płaszow Factory of Bricks and Tiles). The years of German occupation and the war generated the need for natural aggregates. This sped up the process of quarrying and extended it on an industrial scale. The German quarrying industry modernized the exploitation process in the area of the contemporary water body by introducing pumps, the task of which was to minimize the amount of ground water and precipitation accumulating in the borrow pits (which made exploitation more difficult). Thus, the preserved cartographic documents and the scale of their processing do not allow for the precise measuring of the size of the borrow pits during those times (although it gives an approximate picture of the quarrying activities and their characteristics in the region of the present water body).

During the process of phasing out open-cast exploitation (1970s), future reclamation and the adaptation of the pit for recreation and sports was never a priority.

Undertaking reclamation works in the post-exploitation areas compensates for the unfavorable environmental changes caused by the mining activities. Such activities created the beginning of a new, often more-attractive way of managing the transformed area [16]. The adaptation of anthropogenic water bodies in Krakow 
for recreation started only in the second half of the $20^{\text {th }}$ century. Up to the 1950 s, the only object adapted for urban recreation and tourism was the Vistula River. It was a bathing resort and an object adjusted to rowing [10]. Up until the second half of the $20^{\text {th }}$ century, the majority of gravel and sand quarries active within the borders of Krakow were still operating. Among them were Bagry and Zakrzówek.

Bagry is an example of the pro-environmental character of transformation; at the same time, it plays recreational, ecological, landscape, and cultural roles. Due to the natural plant succession in the area of the present water body and adjacent area, an area of rich biodiversity was spontaneously formed. This makes the habitat a haven for many species of flora and fauna. The important factor for the development of the water area and adjacent areas to make a model tourist destination for the city is creating conditions that fulfill the criterion of multi-functionality, preserving the existing natural resources (based on projects and plans). A criterion necessary in the process of the safe revitalization for these types of post-exploitation objects and their adaptation to multiple needs of residents and tourists is a detailed exploration and documentation of the environment. This also refers to the underwater part, which has not been studied in detail or cartographically documented. According to [15], bathymetric data contains key information that can enable us to start habitat studies and classifying various zones of the water body to define their economic or environmental functions. In the case of Bagry, no cartographic documents were preserved to allow us to make conclusions about the morphological characteristic of the water body, which is very important for the safety of visitors in terms of recreation (finding the areas of safe swimming and sailing).

This publication presents the first detailed cartographic documentation in the form of a situation-altitude map and bathymetric map of the main water body of Bagry, which allows us to become familiar with the characteristics of the object and verifies the local myths and contents included in many articles (including scientific ones) referring to the maximal depth and geomorphological profile of the bottom.

\section{Localization of Studied Object}

The water body of Bagry is situated in an industrial part of Krakow called Płaszów, alongside Railway no. 91: Krakow - Medyka (initially the Karol Ludwik Galizien Railway - section Krakow - Lviv) in the neighborhood of a large rail sidetrack, making the transport node for the nearby industry as well as warehouses and rails of the hill yard in Prokocim (freight station Krakow-Prokocim). From the north, the water body is limited by Kozia, Kacza, Marian Batko, and Łanowa Streets consisting of characteristic low buildings (Fig. 1). From the east, Bagry is adjacent to Bagrowa Street, making the borders of the compact industrial-business quarter of Płaszow, while from the west to Żołnierska Street, alongside which small allotments 
and fundaments of demolished industrial halls and the areas of the already non-existent Płaszow Factory of Bricks and Tiles S.A. (using material from the borrow pits) are situated.

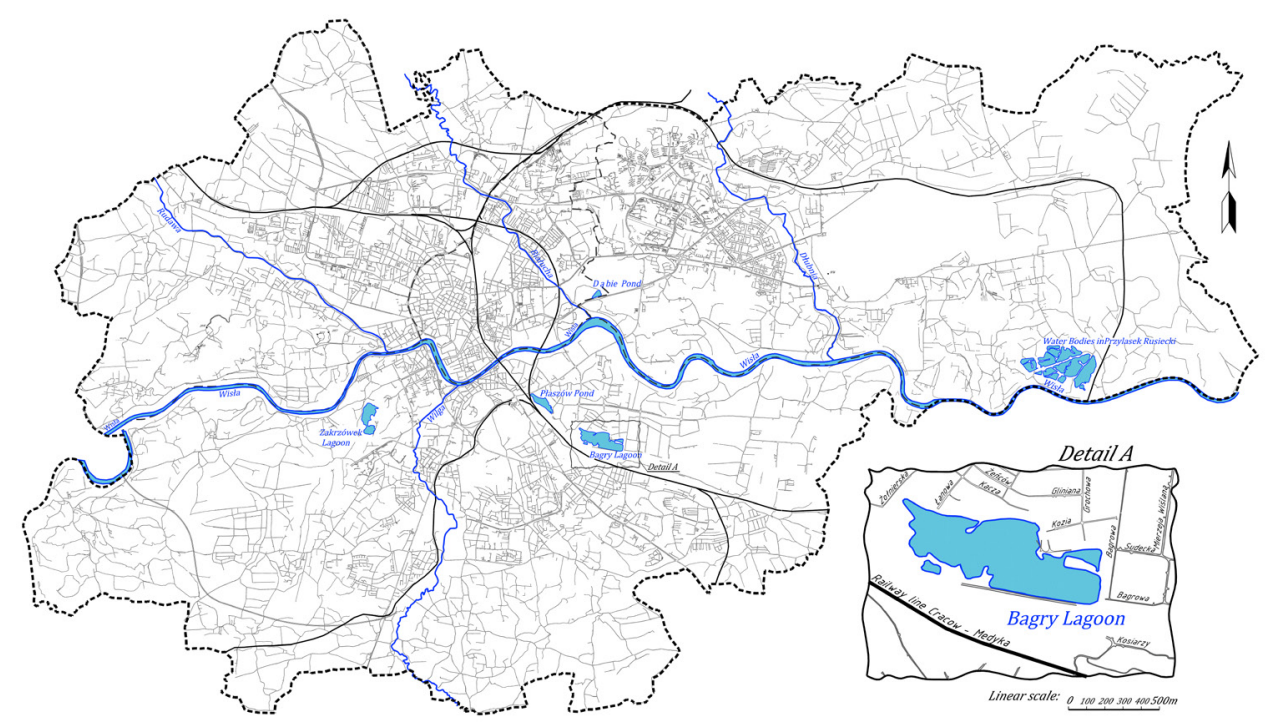

Fig. 1. Localization of Bagry on simplified map of Krakow

\section{Short Characteristics of Applied Measurement Technologies}

The geodetic inventory of the Bagry Reservoir was carried out in two stages using integrated measurements. These measurements included:

- in the part above the water (shoreline and the area adjacent to the water body), carried out with GNSS by Trimble consisting of a two-frequency R8s receiver and TSC3 controller, referring to the points of the existing geodetic network of the third class located in the neighborhood of the water body;

- in the underwater part (hydrographical measurements), made with the use of the above-mentioned GNSS set and the acoustic sonar Lowrence Elite-4x HDI (popular equipment for anglers and sailors).

\section{Measurement Set GNSS Trimble}

Situation-altitude terrestrial measurements (3D) and the positioning of bathymetric checkpoints were carried out with GNSS by Trimble, providing high accuracy of the positioning of coordinates in 2D. This was possible due to the application of the Małopolska System of Precise Positioning (MSPP - Małopolski System Pozycjonowa- 
nia Precyzyjnego), allowing the use of the NAWGEO service making RTK corrections available. Such a system provides positioning with a mean error of $m_{P} \leq \pm 0.03 \mathrm{~m}$ (with the known ordinate of the water table, the vertical component for relatively small water bodies of this type is not significant at the stage of post-processing) [14].

\section{Ultrasonic Sonar Lowrence}

The hydrographical set consisting of the Lowrence Elite-4x HDI ultrasonic sonar, which is equipped in a four-bundle transom converter operating on several frequencies; i.e., 83/200/455/800 kHz [6]. The sonar was equipped with a transmitter of the width of the ultrasonic beam of $60^{\circ}$ or $120^{\circ}$ (angler's mode) and in DSI mode (the mode is selected by the user) operating in a measurement range of $0.2-229 \mathrm{~m}$ (frequency: $83 / 200 \mathrm{kHz}$ ). Due to the application by the producer of the sonar in the DownScan Imaging technology, it is possible to process and insert a detailed projection of the bottom and the objects located in the water. The choice of the DownScan Imaging technology limits the range of the measurement to $91 \mathrm{~m}$ (HDI - Hybrid Dual Imaging), while profiling can be carried out only in the case of setting high frequencies; i.e., $455 \mathrm{kHz}$ or $800 \mathrm{kHz}$. Moreover, the applied technology of Advanced Signal Processing (ASP) facilitates the better separation of the area of the given water body from other objects in the underwater space (fish, flooded objects, and submerged vegetation).

The Lowrence sonar is integrated with the inbuilt GPS module of the positioning accuracy on the GIS level (tourist navigation). This means that the error of marking the geographic coordinates of the point calculating into geodetic coordinates can range within $\pm 1-3 \mathrm{~m}$ [19]. Based on the results of the studies carried out by [21] over the accuracy of manual navigation receivers equivalent to the receivers put into anglers' bathymetric sets, positioning errors range within $\pm 2-3 \mathrm{~m}$ (in SPS - Standard Positioning Service without introducing corrections from the EGNOS geo-reference stations) [20].

Experiments carried out by [4] and [5] allowed for the determination of the real accuracy of the GPS module Lowrence Elite-4x HDI sonar under different working conditions; i.e., static mode (while stationary) and kinematic mode (while moving). The base for the comparison were indications of the GNSS Trimble R8s receiver fixed in the alignment with the GPS module of the Lowrence sonar (set attached to the side of the paddle boat), which allowed for the determination of real absolute errors.

Based on the measurements carried out alongside the profile line in static mode (profile marked with a rope fixed on two opposite shores of the water body), the value of the mean error in the positioning GPS receiver was $m_{P}= \pm 0.93 \mathrm{~m}$ (positioning accuracy with EGNOS correction was $\pm 1.0 \mathrm{~m}$ ). Moreover, based on the comparison of the 2D coordinates of 1405 points obtained in kinematic mode using the GPS Lowrence and GNSS Trimble R8s receivers, the positioning error was defined (which, in this case, was $\left.m_{P}= \pm 2.1 \mathrm{~m}\right)$. Thus, in the case of very differentiated bottom morphology, the accuracy of the model will be determined by the vessel's speed during the hydrographical measurement. 


\section{Influence of External Factors on Correctness of Depth Measurements}

The topographic differentiation in the coastal zone (topographic cover of the horizon) and the presence of trees alongside the shoreline can create the risk of wrongly defining the bathymetric position (in the horizontal plane) of the check points using the GPS module of the Lowrence sonar (above $\pm 3 \mathrm{~m}$ ). As a result of these types of gross errors, the geographic coordinates of the check points can be defined beyond the real outline of the water body. To avoid gross errors when positioning the bathymetric check points, the R8s Trimble geodetic satellite receiver was applied in the measurements. It was coaxially fixed with the ultra-sound converter on a pole fixed to the side of the paddle boat.

Occurring from the moment of the end of the mining exploitation, the succession of coastal vegetation significantly changed the landscape of the water body and spontaneously led to the formation of a biodiversity hot-spot. The same process also occurred in the water body itself. Nowadays, the bottom is covered by a thick layer of silt and submerged vegetation in many places. The most-common species are spiked water-milfoil Myriophyllum spicatum L. (Haloragaceae) and hornwort Ceratophyllum demersum L. (Ceratophyllaceae). During the inventory work, it was stated that the kind of vegetation covering the bottom can be a source of significant errors in measuring the real depth. Due to its size and density, one such plant can disturb the results given by the sonar: Myriophyllum spicatum. This plant is abundant in the waters of Bagry. Even at a depth of six meters, its rapid development is facilitated by the high content of calcium in water that is neutral or slightly alkaline. The water milfoil usually grows on silt-covered or sandy bottoms with the layer of organic sediment. During the most-intensive growth (from May through September), its creeping stems can achieve lengths of up to $5 \mathrm{~m}$. In practice, it makes one-species aggregation in the form of underwater meadows with dense inflorescences. It was stated that this very density disturbs the depth measurement by sonar; the plant itself can make a screen that reflects ultra-sonic waves (flickering depth values on the screen giving the signal that the measurement is unreliable). Thus, during the measurement, one should react to the way of presenting the depth values, observe the speed of their changes, and interpret the multi-color image of the bottom and body of water on the screen of the sonar. The appearance of additional graphical information in the form of "clouds" (in fact, noise) can indicate the presence of a single plant or a larger group of plants (underwater meadows). The example of a "fuzzy" signal resulting from the presence of the vegetation clusters causing the noise is illustrated in Figure 2. In case of doubts about the values shown by the sonar, a control measurement should be conducted with a different frequency, or this value should be verified by applying classical measurement tools; i.e., rod sonar (small depths) or weight sonar (large depths). 
a)

b)

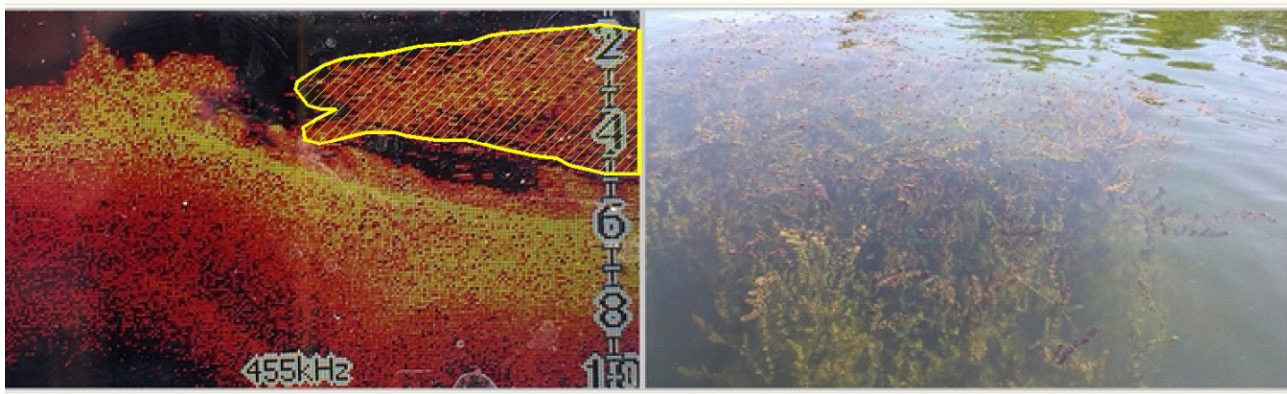

Fig. 2. Example of erroneous (noisy) measurement caused by impact of compact vegetation cluster (for Bagry: spiked water-milfoil Myriophyllum spicatum L. or hornwort Ceratophyllum demersum L.): a) view over aquatic vegetation clusters (milfoil); b) image on screen, with marked zone of dense aquatic vegetation that can disturb records given by sonar

(phot. R. Gawałkiewicz)

In the case of applying sonars with a large conical angle, the value of the error in the depth measurement depends on the depth of the water body, angle of the inclination of the converter from the vertical, and morphological variability of the bottom. Typical of post-mining water bodies (borrow pits), the morphological variability of the excavation causes the energy of the acoustic wave to cover a much larger area than in the case of a flat (horizontal) bottom. Thus, a small inclination of the converter from the vertical generates significant values of measurement errors resulting from the shortening or extending of the measured value in the place of the measurement, which was illustrated in Figure 3.

While preserving the angular and linear indexes, as in Figure 3, the real values of depths $H_{1}$ and $H_{2}$ in the case of the water body measurement along the direction of the inclination of the sonar arm (or the slant height of the cone of the ultrasonic wave) take the following forms:

$$
\begin{aligned}
& H_{1}=H \cdot \frac{\cos \delta}{\cos (\alpha+\delta)} \\
& H_{2}=H \cdot \frac{\cos \delta}{\cos (\alpha-\delta)}
\end{aligned}
$$

where:

$H$ - real depth in the place of the measurement with the ultrasonic sonar,

$\alpha$ - inclination angle of the sonar arm (or half the cone angle of the converter,

$\delta$ - inclination angle of the bottom in the place of depth measurement. 


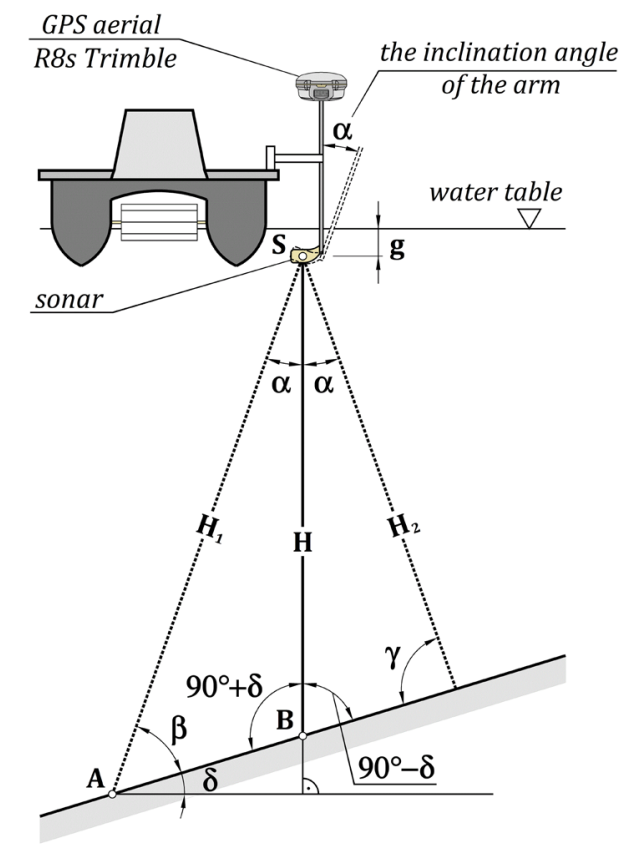

Fig. 3. Influence of bottom inclination angle and inclination angle of arm where sonar is attached on obtained depths

This means that, assuming the calculations for the largest measured depth in Bagry is $H=7.8 \mathrm{~m}$, the maximal angle of the natural dump of sand in a humid state $\delta=27^{\circ}[9]$ and the inclination of the sonar in relation to the vertical line of value $\alpha=10^{\circ}$, we obtain an increase in the length in the direction of the fall of value by $0.51 \mathrm{~m}$ or shortening the length towards the elevation by $0.53 \mathrm{~m}$, preserving the accuracy of the reading system of the sonar at a \pm 0.1 -m level (the actual accuracy of the tested sonar determined by [5] provided by the mean error of depth measurement equals $\pm 0.09 \mathrm{~m}$ ).

\section{Definition of Morphometric Parameters of Bagry}

Integration of the data of depth measurements obtained by the Lowrence Elite-4x HDI ultrasonic sonar (the measurement was carried out for the frequency of an ultrasonic wave of $455 \mathrm{kHz}$ ) and flat coordinates marked with the R8s Trimble receiver made a base for creating a complex cartographic documentation of Bagry. Moreover, spatial coordinates XYG allowed the definition of detailed morphometric characteristic of the water body. In practice, it is a set of parameters determining the quantitative presentation of the shape and dimensions of the bowl of the water body and the volume of the water it contains. 
According to [3], the parameters characterizing any water body include:

- the situation of the water body defined by geodetic or geographic coordinates of the gravity center of the area limited by the coastal line;

- the area of the water body $P$;

- the area of the bottom $P_{\text {bottom }}$ measured down the slope (determined from numeric models);

- the volume of water masses $V$;

- the ordinate of the water table $H_{z w}$ according to the state for the day of the measurement;

- maximal depth $G_{\max }$;

- mean depth of the water body $G_{\text {Mean' }}$ usually counted as:

- the mean of all the points of the depth measurement $\left({ }^{* 1}-\right.$ Table 1$)$;

- the quotient of the water body volume and its area $\left({ }^{* 2}-\right.$ Table 1$)$;

- the mean depth of all nodes of the numerical model based on the regular GRID - for the calculations, the grid of side $2 \times 2 \mathrm{~m}$ based on 73,760 quadrangles of the GRID (*3 - Table 1$)$;

- maximal length $L_{\max }$ (usually represented by a broken line), as the shortest distance between the opposite shores measured alongside the axis of the water body;

- maximal width $S_{\text {max }}$ being the longest section between the opposite shores, measured perpendicularly to the axis of the water body;

- mean width $S_{\text {Mean }}$ usually counted as:

- the ratio between the area of the water body and its maximal length $S_{\text {Mean }}=235.7 \mathrm{~m}\left({ }^{* 4}-\right.$ Table 1$)$;

- the mean from many profiles perpendicular to the longitudinal axis of the water body (based on 52 profiles, mean width of the water body is $S_{\text {Mean }}=218.2 \mathrm{~m}\left({ }^{* 5}-\right.$ Table 1$)$;

- the length of the shoreline $L$;

- depth indicator $W$ defining the shape of the bowl of the water body, being the proportion of mean depth $G_{\text {Mean }}$ to maximal depth $G_{\max }$; the calculations show that this indicator was $W=0.6$, which qualifies the reservoir to the group of water bodies of a semicircular bowl; i.e., $W=2 / 3$;

- the development of the shoreline $K$ (coefficient ranging from 1 to 5), being the proportion of the shoreline length to the circuit of the circle of the area equaling the area of the water body. This parameter is calculated according to Formula [3]:

$$
K=\frac{L}{2 \cdot \sqrt{\pi \cdot P}}
$$

and equals 2.1, which indicates the relatively poor differentiation of the shoreline. The same coefficient $K$ was defined for a post-glacial ribbon lake - Jezioro Węgiereckie, situated in the commune of Pakość (the Inowrocław District) [3]. 
Table 1. Basic morphometric parameters of Bagry Reservoir in Krakow according to state of March 21, 2016 (recreational part)

\begin{tabular}{|c|c|c|c|}
\hline \multicolumn{2}{|c|}{ Morphometric parameter } & $\begin{array}{l}\text { Parameter's sym- } \\
\text { bol }\end{array}$ & Parameter's value \\
\hline \multirow{2}{*}{$\begin{array}{l}\text { Localization of } \\
\text { the water body }\end{array}$} & geodetic coordinates & $X_{\mathrm{s}^{\prime}} Y_{\mathrm{s}}$ & $5,544,541.90,7,427,701.71$ \\
\hline & geographic coordinates & $B, L$ & $\begin{array}{l}50^{\circ} 01^{\prime} 57.61^{\prime \prime}, \\
19^{\circ} 59^{\prime} 26.97^{\prime \prime}\end{array}$ \\
\hline \multicolumn{2}{|c|}{ The area of the water body } & $P$ & $300,266 \mathrm{~m}^{2}$ \\
\hline \multicolumn{2}{|c|}{$\begin{array}{l}\text { The area of the bottom } \\
\text { (based on GRID of } 2 \mathrm{~m} \times 2 \mathrm{~m} \text { side) }\end{array}$} & $P_{\text {bottom }}$ & $321,226.4 \mathrm{~m}^{2}$ \\
\hline \multicolumn{2}{|c|}{ Water mass volume } & V & $1,405,762 \mathrm{~m}^{3}$ \\
\hline \multicolumn{2}{|c|}{$\begin{array}{l}\text { Water table ordinate } \\
\text { state for } 21 / 03 / 2016\end{array}$} & $H_{\mathrm{zw}}$ & 197.457 \\
\hline \multicolumn{2}{|c|}{ Maximal depth of the water body } & $G_{\max }$ & $7.8 \mathrm{~m}$ \\
\hline \multicolumn{2}{|c|}{ Mean depth of the water body } & $G_{\text {Mean }}$ & $-4.55^{(* 1)} /-4.68^{(* 2)} /-4.66^{(* 3)}$ \\
\hline \multicolumn{2}{|c|}{ Maximal length of the water body } & $L_{\max }$ & $1274.1 \mathrm{~m}$ \\
\hline \multicolumn{2}{|c|}{$\begin{array}{l}\text { Maximal width } \\
\text { (localization of the profile as in the scheme-Fig. 4) }\end{array}$} & $S_{\max }$ & $363.6 \mathrm{~m}$ \\
\hline \multicolumn{2}{|l|}{ Width mean } & $S_{\text {Mean }}$ & $235.7 \mathrm{~m}^{(* 4)} 218.2 \mathrm{~m}^{(* 5)}$ \\
\hline \multicolumn{2}{|c|}{ Length of the shoreline } & $L$ & $4092.6 \mathrm{~m}$ \\
\hline \multicolumn{2}{|l|}{ Depth indicator } & $W$ & 0.6 \\
\hline \multicolumn{2}{|c|}{ Coefficient of the shoreline development } & K & 2.1 \\
\hline
\end{tabular}

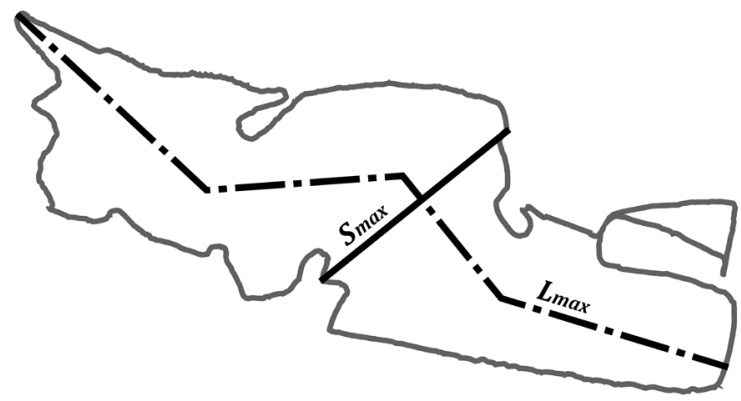

Fig. 4. Scheme of Bagry Reservoir

The calculation of the volume of water resources requires an assessment of the accuracy of determining the parameter of volume $V$. In the literature, one can find many formulae defining the accuracy of the determination of the volume of water resource or earth mass $m_{V}[7,17]$. The selection of a proper algorithm of calculations 
should be adjusted to the character of the measurement data and type of the specially made model. Contained in Table 1, volume value $V$ of the Bagry Reservoir was based on a GRID of the $2 \mathrm{~m} \times 2 \mathrm{~m}$ side formed by the kriging method (the choice of method was because of the irregularity of the distribution of points) in Surfer by the Golden Software program. The characteristics of the model based on a regular GRID of squares (in 3D - prisms of a square or rectangular base) implied the method of accuracy assessment and choice of formula to define the error of the measurement of volume $m_{V}$. If the error of horizontal coordinates is neglected, the value of the error referring to water volume was based on relationship [2]:

$$
m_{V}= \pm \sqrt{\left(m_{z} \cdot \sqrt{P \cdot P_{0}}\right)^{2}+\left(m_{0} \cdot \sqrt{\frac{P}{4}}\right)^{2}+\left(\frac{1}{2} \cdot \varepsilon_{\max } \cdot P_{0} \cdot \sqrt{n}\right)^{2}}
$$

where:

$m_{z}$ - the mean acceptable error of the surface projection, which was taken as the mean value of the residue defining the degree of fitting the GRID model to the distribution of the points of bathymetric measurements; based on point set of the parameters of GRID in the Surfer program, the value of the projection error was defined as $m_{z}= \pm 0.136 \mathrm{~m}$;

$P$ - the area of the Bagry Reservoir (Tab. 1);

$P_{0}$ - the area of the individual quadrangle of GRID, $P_{0}=4 \mathrm{~m}^{2}$;

$m_{0}$ - the mean error of depth measurement, resulting from the specification used in the measurement of the ultrasonic sonar, $m_{0}= \pm 0.10 \mathrm{~m}$;

$\varepsilon_{\max }$ - the greatest distance between the spherical area and the area of the square, the same as the value of the maximal depth; i.e., $\varepsilon_{\max }=7.8 \mathrm{~m}$;

$n$ - the number quadrangles of dimension $2 \mathrm{~m} \times 2 \mathrm{~m}$ covering the area of the water body, $n=73760$.

The above formula indicates that, at a volume of the water body on a level of $V=1,405,762 \mathrm{~m}^{3}$, the mean error of the definition of the value of the volume is $m_{V}= \pm 4239.5 \mathrm{~m}^{3}$, which makes the relative error $\pm 0.3 \%$.

\section{Bathymetric Map and Accuracy Assessment of Numerical Model of Bottom}

Integration of the spatial measurement data (i.e., GNSS, total station measurements, bathymetric, and vector measurements [situation-height map of the adjacent areas]), allows us to make a detailed DTM. The possibility of processing the large quantity of spatial data is guaranteed by the Surfer v. 9 (interpolation techniques) 
and AutoCAD v. 2010 (vector map) programs. Combining the possibilities of both programs allowed for the first-of-its-type cartographic documentation of the Bagry Reservoir (Fig. 5).

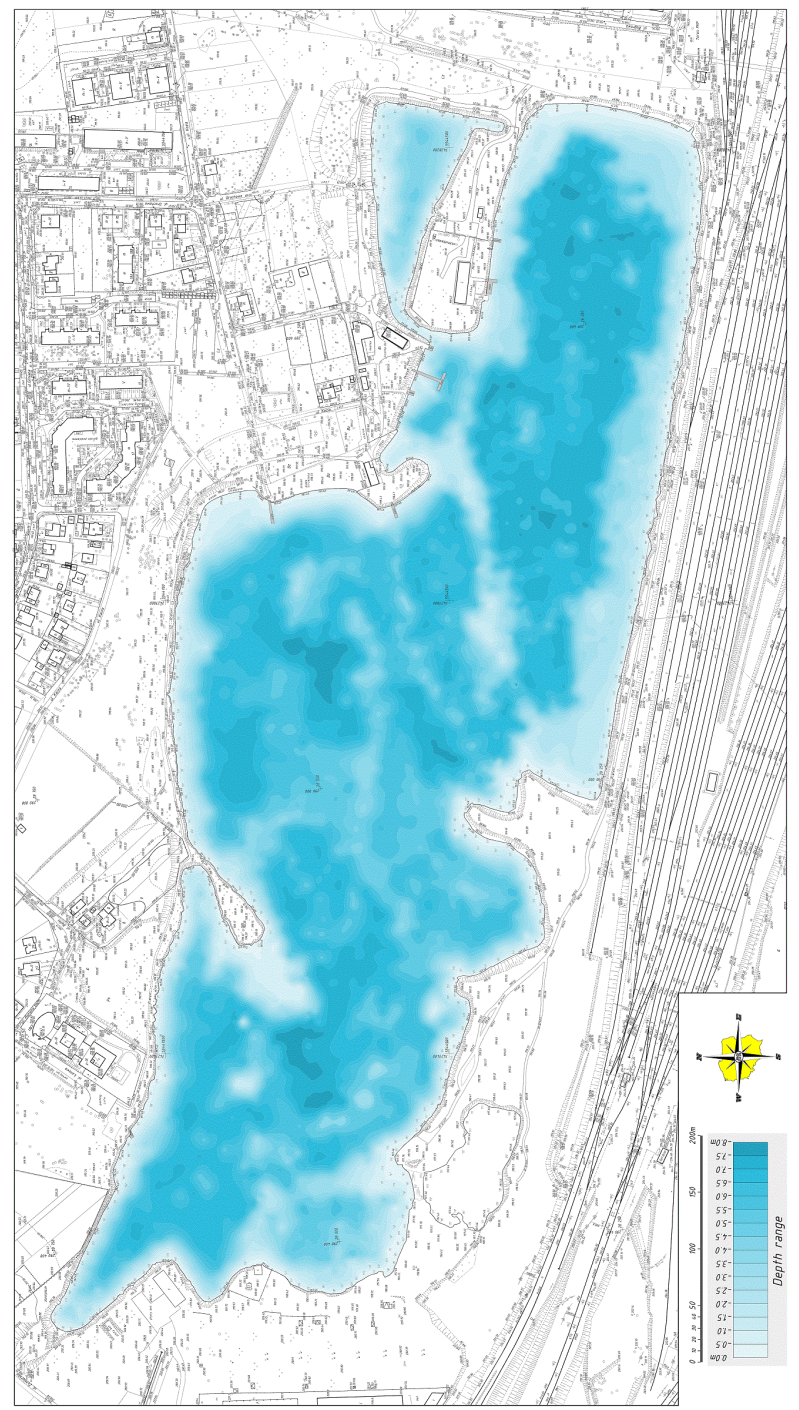

Fig. 5. Bathymetric map of Bagry

Problems with making digital models of terrain (layer maps) is strongly connected with the application of advanced geo-statistic methods [20]. In their engineering practice, the most-often-applied interpolation method is kriging if a linear trend is presumed. 
In carrying out the engineering task, two interpolation methods are applied; i.e., kriging and triangulation with linear interpolation. The choice of interpolation algorithm depends on the characteristic of the distribution of the data (regularity of the data grid). Despite the fact that they are based on different algorithms of the mathematical transformation of data, they allow us to obtain graphic effects that are closest to the real model of the studied phenomenon. Hydrographical measurements of water bodies with irregular shorelines and width variables do not allow for complex measurements alongside the marked regular transverse or longitudinal profiles.

Thus, the method of disperse points is usually applied in such cases, and the selection of the place measurements in such a case depends on the following:

- the assumed degree of generalization of the created model; i.e., the compliance of the 3D projection of the surface;

- the degree of the morphological differentiation of the area.

The measurement method is based on the set of dispersed points. It forces the method of processing the point data into a 3D or pseudo-3D model. In the case of the uneven distribution of points and great geomorphologic differentiation of the bottom, the best results of the spatial estimation of the model to the points of bathymetric measurement (in terms of geostatistic adjustment) are guaranteed by the kriging method [21]. This means that a usual kriging - point kriging (often called the best linear unbiased estimator, making "smoothed" models) is an often-used technique of estimating points in the places where a measurement has not been made. This method is connected with the estimation of the value of a given parameter for a concrete point (in the analyzed case - depth), bearing in mind the value of the neighboring points [9]. Thus, kriging is the best linear unbiased estimator because it minimizes the variance of errors as compared to other methods of estimation (which do not do that); this can be confirmed by the results of the analysis of the selected numerical models [5].

Based on the model created in the Surfer v.9 program, the model of the bottom is made with the kriging method based on the estimation of the value of points in the nodes of the interpolation grid $(2 \mathrm{~m} \times 2 \mathrm{~m})$. Based on the set of 3D data XYG of the bathymetric measurement and the shoreline, one can make its qualitative assessment in terms of the accuracy in modeling the phenomenon (geomorphology of the bottom). An excellent tool for the assessment is the estimation error (residuum) being the difference between estimated value $G^{*}\left(x_{i}\right)$ and the value of random variable $G^{i}\left(x_{i}\right)$, which models the real value [22] and is expressed by the following formula:

$$
R\left(x_{i}\right)=G \cdot\left(x_{i}\right)-G^{i}\left(x_{i}\right)
$$


A graphical image of the distribution of residua (the range of errors) for the whole area of the water body as well as the points of bathymetric measurements are illustrated in Figure 6.

Analyzing the distribution of the residua of the values exceeding the accuracy of the ultrasonic sonar, one should pay attention to the localization and characteristics of the zones of the largest values. It is made by the areas localized in the regions of the greatest morphological changes; i.e., steep slopes of a post-exploitation trough and the areas of the liquidation of the levee that used to divide the water body into smaller water units.

The qualitative assessment of the created model (based on kriging) can be based on the analysis of the value of the following:

- mean error (ME), defined in geostatistics (also mean rudimentary error), which indicates the mean difference between the predicted value and the measured value; this error (its value should be close to 0 ) is defined by the following equation:

$$
M E=\frac{\sum_{i=1}^{n} R\left(x_{i}\right)}{n}= \pm 0.0001 \mathrm{~m}
$$

- mean squared error (MSE), which provides information on how much the estimated values are close to the real (measured) value; this error is defined by the following equation:

$$
M S E=\frac{\sum_{i=1}^{n}\left[R\left(x_{i}\right)\right]^{2}}{n}= \pm 0.0094 \mathrm{~m}
$$

- root mean squared error (RMSE), showing the accuracy of the topographic surface; the value of this error is defined by Equation [17]:

$$
R M S E=\sqrt{\frac{\sum_{i=1}^{n}\left[R\left(x_{i}\right)\right]^{\text {of area }}}{n}}= \pm 0.0968 \mathrm{~m}
$$

where:

$R\left(x_{i}\right)$ - value of the residuum (residual error) at the point of direct hydrographical measurement; this number makes the difference between the value of the depth of the interpolated point and the corresponding value of the depth of the measurement (control) point;

$n$ - number of variables $n=6805$ (altogether: points of depth measurement - 5724; and shoreline measurement - 1081). 


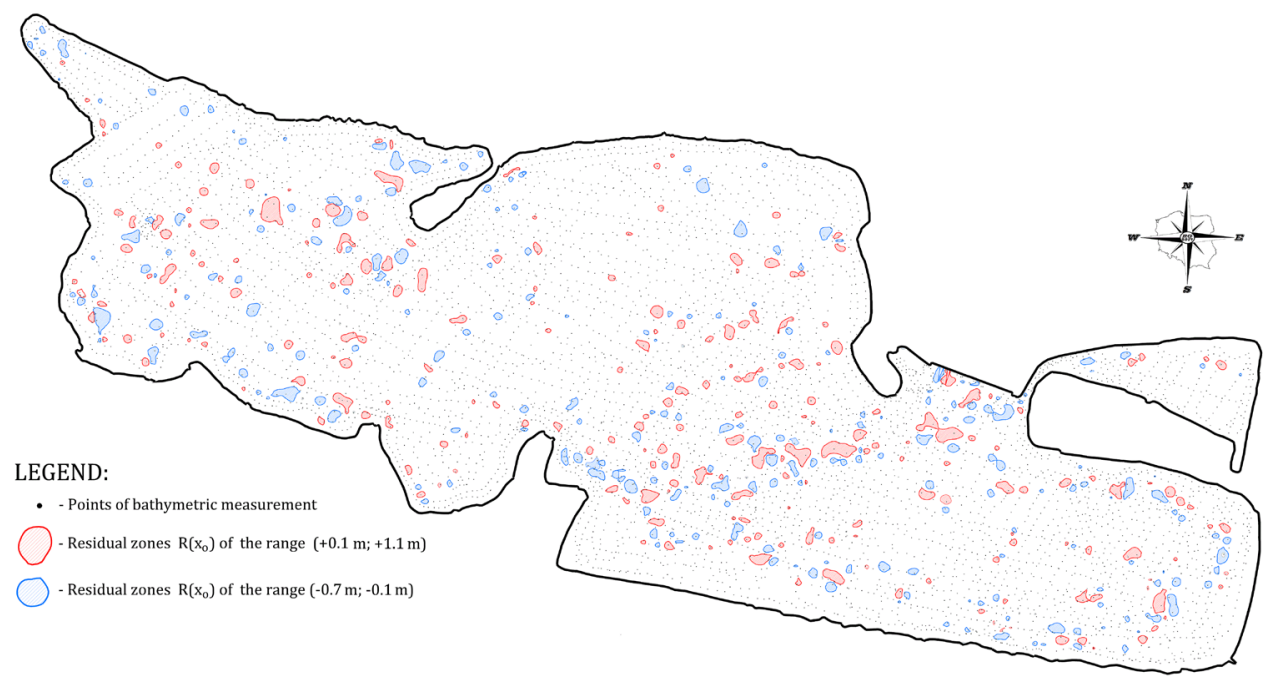

Fig. 6. Graphical distribution of residua of values exceeding $\pm 0.10 \mathrm{~m}$ (image method with application of signature marks) on background of Bagry Reservoir and points of hydrographical measurement

The total area of the plots of the value of residuum exceeding $\pm 0.10 \mathrm{~m}$ is $16,969 \mathrm{~m}^{2}$, which makes $5.6 \%$ of the area of water body (density of measurement points: 1 point per approx. $44 \mathrm{~m}^{2}$ ).

\section{Conclusions}

Chosen by the city authorities, urban directions of the development of Krakow defined in the City Plan of Urban Land Management (MPZPM) can indicate slow but steady effort in transforming post-mining areas located near the center into areas friendly to the residents. With its adjacent areas of greenery, Bagry was included in the Study of Land Management for the city of Krakow (Studium zagospodarowania przestrzennego miasta Krakowa) to "a zone of management of the ecological system of the city greenery and river parks" to preserve natural values [7, 11, 12]. Thus, obtaining the best effects of the adjustment of the function to the field conditions requires a detailed inventory of the object (including geodetic documentation). A detailed model of the bowl of the Bagry Reservoir as well as the data on the surface of the area around the water body can provide significant information in the decision-making process over the proper assessment of alternative varieties of the adaptation of the respective fragments of the water body for recreation, sports, protection of nature and landscape, educational purposes, etc. The created bathymetric documentation 
allows for the conclusion that the geomorphology of the water body's bottom perfectly reflects the history and character of exploitation carried out in the respective regions of the water body during various times of the mining activity. In the southeast part, a relatively flat bottom and the geometrically regular shape of the water body bowl can be observed (dry terrestrial exploitation carried out during Nazi occupation). Obtaining such a regular shape in the excavation was possible owing to the work of pumps removing ground water and precipitation that accumulated in the exploitation trough as well as facilitating easy access to the resources. The geomorphology of the bottom of the water body in the northwest part is the effect of chaotic exploitation and the conditions of quarrying.

Linking geological information with the cartographic content of the situation - height map, including the water part (bathymetric part - Fig. 4) allows for the statement that the sand and gravel beds were exploited to almost the lining layer (Miocene basis). The generated model of the bottom makes a perfect tool of control of the resources in the water over time. A great number of observations have allowed us to make a detailed and reliable geomorphologic model of the bottom with high projection accuracy. This is shown by the value of the square root of mean square root RMSE. It has been estimated that the value of this error is smaller than the error of the measurement of the depth of the applied Lowrence Elite-4x HDI sonar.

The author would like to thank Mr. Ireneusz Kaczmarek of the association "Omega" for providing the paddle boats for the needs of the hydrographical measurements.

\section{References}

[1] Bedla D., Petryk A.: Funkcjonowanie wyrobiskowych zbiorników wody w Przegini pod Krakowem. Inżynieria Ekologiczna, nr 22, 2010, pp. 83-89.

[2] Borowiecki A.: Numeryczny model terenu w aspekcie projektowania i budowy obiektów inżynierskich. Zeszyty Naukowe Akademii Rolniczej im. H. Kołłątaja w Krakowie. Rozprawy, nr 193, Wyd. Akademii Rolniczej, Kraków 1994.

[3] Choiński A.: Limnologia fizyczna Polski. Wydawnictwo Naukowe Uniwersytetu im. Adama Mickiewicza, Poznań 2008.

[4] Chudzik J., Jaszczyszyn I.: Dokładność numerycznego modelu terenu tworzonego w oparciu o pomiary batymetryczne, GNSS oraz program "Surfer" na wybranym fragmencie Zalewu Bagry (część wschodnia). AGH, Kraków 2016 [M.Sc. thesis, unpublished].

[5] Dudek M., Maciejko M.: Dokładność numerycznego modelu terenu tworzonego w oparciu o pomiary batymetryczne, GNSS oraz program "Surfer" na wybranym fragmencie Zalewu Bagry (czẹść zachodnia). AGH, Kraków 2016 [M.Sc. thesis, unpublished].

[6] Echosonda.pl, Lowrance Elite-4x HDI, [on-line:] www.echosonda.pl/ lowrance-elite-4x-hdi.html [access: 1.11.2017]. 
[7] Maciaszek J.: Skanowanie laserowe jako nowa technologia inwentaryzacji i wizualizacji zabytkowych komór solnych. Gospodarka Surowcami Mineralnymi, t. 24, z. 3/2, 2008, pp. 197-212.

[8] Magazynowanie i sktadowanie. 9.7. Standard pracy. Skanska, [on-line:] http:// studylibpl.com/doc/640997/09.07-magazynowanie-i-sk\%C5\%82adowanie [access: 1.11.2017].

[9] Namysłowska-Wilczyńska B.: Geostatystyka: teoria i zastosowania. Oficyna Wydawnicza Politechniki Wrocławskiej, Wrocław 2006.

[10] Orlewicz-Musiał M., Wagner A.: Ekologiczne, kulturowe i rekreacyjne aspekty rewitalizacji, ze szczególnym uwzględnieniem terenów zieleni prawobrzeżnej części Krakowa. [in:] Skowronek J. (red. nauk.), Innowacyjne rozwiazania rewitalizacji terenów zdegradowanych: praca zbiorowa. T. 8, Instytut Ekologii Terenów Uprzemysłowionych, Katowice 2016, pp. 247-260.

[11] Pietrzyk-Sokulska E.: Zbiorniki wodne w wyrobiskach pogórniczych - nowy element atrakcyjności krajobrazu miasta. [in:] Andrejczuk W. (red. nauk.), Krajobraz a turystyka, Prace Komisji Krajobrazu Kulturowego, nr 14, Komisja Krajobrazu Kulturowego PTG, Sosnowiec 2010, pp. 264-272.

[12] Pietrzyk-Sokulska E.: Zbiorniki wodne w województwie małopolskim jako istotny element jakości środowiska. Cz. 2 Charakterystyka wybranych, antropogenicznych zbiorników wodnych województwa małopolskiego. Zeszyty Naukowe Instytutu Gospodarki Surowcami Mineralnymi i Energią Polskiej Akademii Nauk, nr 80, 2011, pp. 37-65.

[13] Pociask-Karteczka J.: Przemiany stosunków wodnych na obszarze Krakowa. Zeszyty Naukowe Uniwersytetu Jagiellońskiego. Prace Geograficzne, z. 96, 1994, pp. 7-53.

[14] Rzepecka Z., Antosiewicz M., Bakuła M., Chaberski K., Kudrys J., Walasek A.: Wytyczne techniczne G-1.12. Pomiary satelitarne oparte na systemie precyzyjnego pozycjonowania ASG-EUPOS. Główny Geodeta Kraju, Warszawa 2008.

[15] Snyder A.G., Lacy J.R., Stevens A.W., Carlson E.M.: Bathymetric survey and digital elevation model of Little Holland Tract, Sacramento-San Joaquin Delta, California. Open-File Report 2016-1093, U.S. Geological Survey, Reston 2016.

[16] Wagner A., Orlewicz-Musiał M.: Functions and dysfunctions of tourism and recreation and how they influence aquatic environments. Polish Journal of Environmental Studies, vol. 23, no. 3, 2014, pp. 1045-1050.

[17] Wenrly J.F., Zajd H.J., Coon W.F.: Bathymetric Survey and Estimation of Storage Capacity of Lower Sixmile Creek Reservoir, Ithaca, New York. Open-File Report 2016-1157, U.S. Geological Survey, Reston 2016.

[18] Wicher A.: Mapa batymetryczna zalewu Kryspinów I. Uniwersytet Pedagogiczny im. Komisji Edukacji Narodowej, Wydział Geograficzno-Biologiczny, Instytut Geografii, Kraków 2009 [M.Sc. thesis, unpublished]. 
[19] Wysocki J., Orłowski P.: Analiza wpływu dokładności numerycznego modelu powierzchni terenu na obliczanie objętości mas ziemnych przy projektowaniu obiektów inżynierskich. Przegląd Naukowy Inżynieria i Kształtowanie Środowiska, nr 2, 21, 2012, pp. 58-64.

[20] Zarychta R., Zarychta A.: Zastosowanie krigingu zwyczajnego do rekonstrukcji $i$ wizualizacji reliefu w miejscach odkrywkowej eksploatacji piasku. Archiwum Fotogrametrii, Kartografii i Teledetekcji, vol. spec., 2013, pp. 133-146.

[21] Zawadzki J.: Metody geostatystyczne dla kierunków przyrodniczych i technicznych. Oficyna Wydawnicza Politechniki Warszawskiej. Warszawa 2011.

[22] Zielina L., Mroczek J.: Zastosowanie ręcznych odbiorników nawigacyjnych GPS w pracach geologicznych. Czasopismo Techniczne, z. 2, 2007, pp. 239-247.

\section{Wykorzystanie zintegrowanych technologii pomiarowych w inwentaryzacji Zalewu Bagry}

Streszczenie: Krakowskie zbiorniki wodne pochodzenia antropogenicznego stanowią atrakcyjny element krajobrazu miasta. Do największych i najbardziej wartościowych pod względem przyrodniczo-krajobrazowym, gospodarczym oraz rekreacyjnym należą: zalew Bagry, Staw Płaszowski, zalew Zakrzówek i zespół zbiorników wodnych w Przylasku Rusieckim. Na szczególną uwagę zasługuje zalew Bagry znajdujący się w pobliżu centrum miasta, który pomimo użytkowania już od lat 70 . XX wieku nie doczekał się gruntownej inwentaryzacji. Prowadzone dotychczas badania naukowe koncentrowały się tylko na wybranych elementach geosfery, tj. zasobach flory i fauny (biosfera i hydrosfera) oraz zasobach złóż kruszyw naturalnych, gliny i iłów badanych otworami geologiczno-inżynierskimi (litosfera). Dotychczas część podwodna zbiornika nie była udokumentowana pod względem geomorfologicznym, choć od wielu lat Bagry stanowią atrakcyjne kąpielisko w centrum Krakowa oraz obiekt sportowy. W wielu opracowaniach naukowych i artykułach prasowych można znaleźć szereg wzmianek o wybranych parametrach morfometrycznych, lecz w dużej mierze podawane wartości są nieprawdziwe i niezgodne ze stanem rzeczywistym, wymagają zatem weryfikacji.

Dziś zespoły geodezyjne dysponują narzędziami pomiarowymi i informatycznymi, które pozwalają na tworzenie map sytuacyjno-wysokościowych (powierzchni) oraz opracowań hydrograficznych (map batymetrycznych), co umożliwia wykonanie charakterystyki terenów wodnych, a w dalszej kolejności ich przystosowanie do celów rekreacyjnych, sportowych, dydaktycznych, edukacyjnych, przyrodniczych itp. W artykule przedstawiono wyniki pomiarów hydrograficznych zalewu Bagry oraz pełną analizę parametrów morfometrycznych zbiornika.

\section{Słowa}

kluczowe: zalew Bagry, pomiary hydrograficzne, inwentaryzacja i monitoring zasobów wodnych 